\title{
Interaction of prothrombin with factor Va-phospholipid complexes
}

Citation for published version (APA):

van der Waart, P., Hemker, H. C., \& Lindhout, T. (1984). Interaction of prothrombin with factor Vaphospholipid complexes. Biochemistry, 23(12), 2838-2842. https://doi.org/10.1021/bi00307a047

Document status and date:

Published: 01/06/1984

DOI:

10.1021/bi00307a047

Document Version:

Version created as part of publication process; publisher's layout

\section{Please check the document version of this publication:}

- A submitted manuscript is the version of the article upon submission and before peer-review. There can be important differences between the submitted version and the official published version of record.

People interested in the research are advised to contact the author for the final version of the publication, or visit the DOI to the publisher's website.

- The final author version and the galley proof are versions of the publication after peer review.

- The final published version features the final layout of the paper including the volume, issue and page numbers.

Link to publication

\footnotetext{
General rights rights.

- You may freely distribute the URL identifying the publication in the public portal. please follow below link for the End User Agreement:

www.umlib.nl/taverne-license

Take down policy

If you believe that this document breaches copyright please contact us at:

repository@maastrichtuniversity.nl

providing details and we will investigate your claim.
}

Copyright and moral rights for the publications made accessible in the public portal are retained by the authors and/or other copyright owners and it is a condition of accessing publications that users recognise and abide by the legal requirements associated with these

- Users may download and print one copy of any publication from the public portal for the purpose of private study or research.

- You may not further distribute the material or use it for any profit-making activity or commercial gain

If the publication is distributed under the terms of Article $25 \mathrm{fa}$ of the Dutch Copyright Act, indicated by the "Taverne" license above, 
Reprinted from Biochemistry, 1984, 23, 2838

Copyright (c) 1984 by the American Chemical Society and reprinted by permission of the copyright owner.

\title{
Interaction of Prothrombin with Factor Va-Phospholipid Complexes ${ }^{\dagger}$
}

\author{
Piet van de Waart, ${ }^{\ddagger}$ H. Coenraad Hemker, and Theo Lindhout*
}

ABSTRACT: The effects of factor $\mathrm{Va}$ and the phospholipidbinding fragment of factor Va [factor Va light chain (LC), $\left.M_{\mathrm{r}} 80000\right]$ on the binding of prothrombin, factor X, and factor $\mathrm{Xa}$ to phospholipid vesicles are reported. Equilibrium binding experiments were performed that utilized large-volume vesicles, which can be removed from the bulk solution by centrifugation. Factor $\mathrm{Va}$ decreased the dissociation constant of the prothrombin-phospholipid complex 50-fold, from $2.0 \times 10^{-7} \mathrm{M}$ to $4.0 \times 10^{-9} \mathrm{M}$. For the factor $\mathrm{X}$-phospholipid complex the decrease was 60 -fold $\left(1.8 \times 10^{-7} \mathrm{M}\right.$ to $\left.3.0 \times 10^{-9} \mathrm{M}\right)$ and for factor Xa, 160 -fold $\left(1.6 \times 10^{-7} \mathrm{M}\right.$ to $\left.1.0 \times 10^{-9} \mathrm{M}\right)$. The ratios of moles of protein bound to moles of total added factor $\mathrm{Va}$ at saturation of phospholipid-bound factor $\mathrm{Va}$ indicate an 1:1

\footnotetext{
C
} onversion of prothrombin into thrombin by factor $\mathrm{Xa}$ is most efficient in the presence of factor $\mathrm{Va}$ and membranes containing acidic phospholipids. Rosing et al. (1980) demonstrated that phospholipids lower the $K_{\mathrm{m}}$ for prothrombin, while factor $\mathrm{Va}$ increases the $V_{\max }$ of thrombin formation.

Equilibrium binding experiments employing various techniques have indicated that the interaction of prothrombin and factor Xa with acidic phospholipid is mediated by calcium ions (Nelsestuen \& Lim, 1977; Mayer et al., 1983). However, factor $\mathrm{Va}$ associates with membranes directly by interacting with the polar head groups of the acidic phospholipids (van de Waart et al., 1983).

It is well appreciated that a phospholipid surface is required for a proper assembly of the proteins involved in prothrombin activation. The formation of the catalytic unit, a stoichiometric (1:1) factor $\mathrm{Xa}$-factor $\mathrm{Va}$ complex with a dissociation constant of $3 \times 10^{-9} \mathrm{M}$, is stimulated by acidic phospholipids, resulting in a phospholipid-bound factor $\mathrm{Xa}$-factor $\mathrm{Va}$ complex with a dissociation constant of approximately $10^{-10} \mathrm{M}$ (Nesheim et al., 1979; Lindhout et al., 1982).

Localization of the prothrombinase complex on a phospholipid surface per se, as facilitated by factor Va, does not

\footnotetext{
${ }^{\dagger}$ From the Department of Biochemistry, Rijksuniversiteit Limburg, Maastricht, The Netherlands. Received August 19, 1983.

$\ddagger$ P.v.d.W. was supported by the Netherlands Organization for the Advancement of Pure Scientific Research (Z.W.O.).
}

stoichiometric complex of either factor $\mathrm{Xa}$, factor $\mathrm{X}$, or prothrombin and phospholipid-bound factor $\mathrm{Va}$. In the presence of factor $\mathrm{Va} \mathrm{LC}$, the dissociation constants of factor $\mathrm{Xa}-$ and prothrombin-phospholipid complexes were increased, while the maximal protein-binding capacities of the vesicles were not affected by factor Va LC. The data suggest a competitive interaction between factor $\mathrm{Xa}$ and factor $\mathrm{Va} \mathrm{LC}$ binding as well as between prothrombin and factor Va LC binding at the phospholipid surface. From this, it is concluded that the phospholipid-binding fragment of factor $\mathrm{Va}$ alone does not serve as the binding site for interactions of factor $\mathrm{Xa}$ and prothrombin with factor $\mathrm{Va}$.

explain the effect of factor $\mathrm{Va}$ on the catalytic efficiency of factor $\mathrm{Xa}$. To that end, a role of factor $\mathrm{Va}$ in the formation of the enzyme-substrate complex was proposed (Esmon \& Jackson, 1974; Rosing et al., 1980). However, quantitative studies of the interaction of prothrombin with factor $\mathrm{Va}-$ phospholipid complexes have not been reported.

In a recent report, Tracy \& Mann (1983) described experiments indicating that the interaction of factor $\mathrm{Va}$ with the platelet surface is mediated primarily through factor Va LC, ${ }^{1}$ the 80000 -dalton subunit of factor Va. This observation is consistent with our results using artificially prepared phospholipid membranes (van de Waart et al., 1983). Tracy \& Mann (1983) suggested that the 80000 -dalton subunit of factor $\mathrm{Va}$ alone provides the binding site for the interaction of factor $\mathrm{Xa}$ with platelet-bound factor $\mathrm{Va}$. If artifically prepared phospholipid membranes are a suitable model for the biological membrane surface (platelets), then these results are not in agreement with our observation that the calcium-mediated interaction between the subunits of factor $\mathrm{Va}$ is required for factor Xa binding (Lindhout et al., 1982).

In this paper, we describe experiments indicating that the binding of prothrombin to membranes containing acidic phospholipids is facilitated by factor Va. We further demonstrate that the phospholipid-binding subunit of factor $\mathrm{Va}$

\footnotetext{
${ }^{1}$ Abbreviation: LC, light chain.
} 
$\left(M_{\mathrm{r}} 80000\right)$ does not exhibit this effect but competes with factor $\mathrm{Va}$, factor' $\mathrm{Xa}$, and prothrombin for the same phospholipid-binding sites (i.e., acidic phospholipids).

\section{Materials and Methods}

Ovalbumin and 1,2-dioleoyl-sn-glycero-3-phosphocholine (DOPC) were obtained from Sigma. All other chemicals were of analytical grade. Factor Xa and thrombin activity was determined with the chromogenic substrates $N$-benzoyl-Lisoleucyl-L-glutamylpiperidylglycyl-L-arginine- $p$-nitroanilide hydrochloride (S2237) and H-D-phenylalanyl-L-pipecoyl-Larginine- $p$-nitroanilide dihydrochloride (S2238) (Kabi Diagnostics), respectively.

The following bovine clotting factors were prepared: prothrombin (Owen et al., 1974), thrombin (Rosing et al., 1980), factor $\mathrm{V}$, factor $\mathrm{Va}$, and factor $\mathrm{Va}$ subunits (Lindhout et al., 1982), factor X (Fujikawa et al., 1972a), and factor Xa (Fujikawa et al., 1972b).

Functional molar concentrations of factor Va and factor Va subunits, factor $\mathrm{Xa}$, and prothrombin were estimated according to van de Waart et al. (1983), van Dieijen et al. (1981), and Rosing et al. (1980), respectively.

1,2-Dioleoyl-sn-glycero-3-phosphoserine (DOPS) was prepared according to the method described by Comfurius \& Zwaal (1977).

Large-volume unilamellar vesicles were prepared by the ether injection method according to Deamer \& Bangham (1976) as previously described (van de Waart et al., 1983). Whenever a membrane composition is expressed as a percentage of acidic phospholipid, the remaining phospholipid is DOPC.

Phospholipid concentrations were determined by the method of Böttcher et al. (1961).

Binding of proteins to large-volume vesicles was quantitated by measuring the molar concentrations of the proteins prior to and after centrifugation for $30 \mathrm{~min}$ at $30000 \mathrm{~g}$ and $20^{\circ} \mathrm{C}$. Prior to centrifugation an equilibrium exists between free protein and phospholipid-bound protein. So

$$
K_{\mathrm{d}}=S_{\mathrm{f}}(F / B)
$$

where $K_{\mathrm{d}}$ is the dissociation constant of the protein-phospholipid complex, $S_{\mathrm{f}}$ is the concentration of uncomplexed (free) binding sites, $F$ is the concentration of free protein, and $B$ is the concentration of bound protein. As sedimentation occurs, both $S_{\mathrm{f}}$ and $B$ increase and, so, $K_{\mathrm{d}}$ will not change. Therefore, the equilibrium distribution is maintained after the separation of the vesicles from the bulk solution. Protein binding data were analyzed by double-reciprocal plots of the concentrations of bound protein vs. free protein (van de Waart et al., 1983). All binding experiments were carried out in a buffer containing $50 \mathrm{mM}$ tris(hydroxymethyl)aminomethane (Tris), $100 \mathrm{mM}$ $\mathrm{NaCl}, 0.5 \mathrm{mg}$ of ovalbumin/mL, and $3 \mathrm{mM} \mathrm{CaCl}_{2}, \mathrm{pH} 7.5$.

Results

Initial Experiments. Quantitative binding studies, employing various techniques, on the interaction of factor Xa with artificially prepared membranes as well as with platelets in the presence of factor Va have been reported (Nesheim et al., 1979; Tracy et al., 1981; Lindhout et al., 1982).

As yet, no such studies have been described on the factor Va-prothrombin interaction at a phospholipid surface. A simple and direct binding technique, utilizing large-volume vesicles that can be removed from the bulk solution by centrifugation, is a valuable tool in the investigation of proteinprotein interactions at a phospholipid surface (van de Waart et al., 1983).

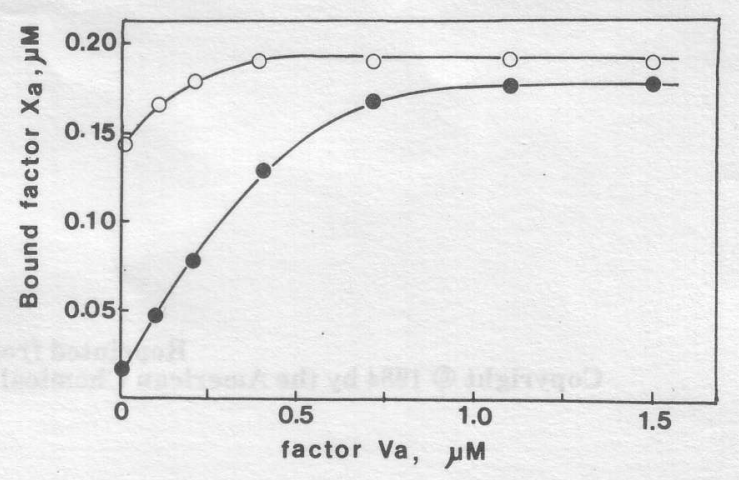

FIGURE 1: Binding of factor Xa to 5\% DOPS (-) and 20\% DOPS (O) vesicles in the presence of varying concentrations of factor $\mathrm{Va}$. Binding measurements were made following a $10-\mathrm{min}$ incubation. The factor Xa concentration was kept constant at $2.0 \times 10^{-7} \mathrm{M}$. The phospholipid concentrations were either $2.0 \times 10^{-4}$ (5\% DOPS) or $5.0 \times 10^{-5} \mathrm{M}(20 \%$ DOPS $)$. Points are the means of three determinations on separate mixtures.

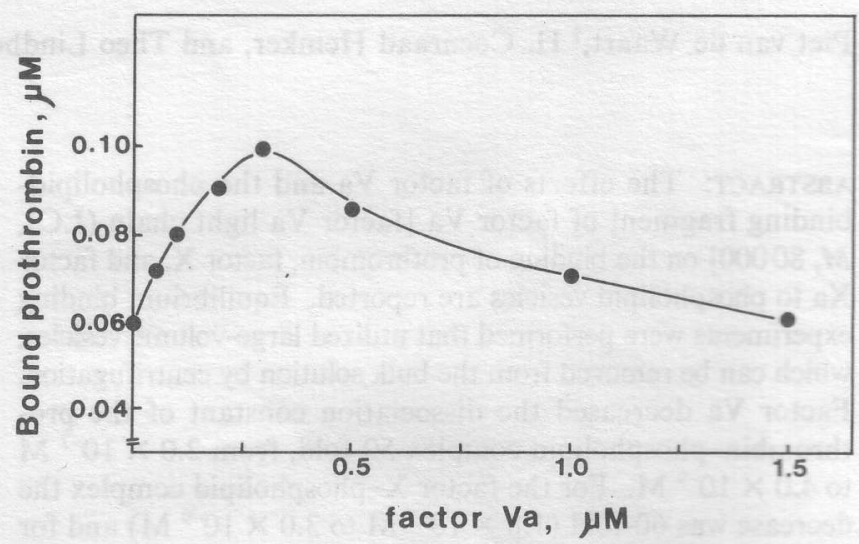

FIGURE 2: Binding of prothrombin to $20 \%$ DOPS vesicles in the presence of varying concentrations of factor $\mathrm{Va}$. The prothrombin concentration was kept constant at $2.0 \times 10^{-7} \mathrm{M}$. The phospholipid concentration was $1.0 \times 10^{-4} \mathrm{M}$. Points are the means of three determinations on separate mixtures.

Using this technique, we found that the amount of factor $\mathrm{Xa}$ associated with vesicles containing 5\% DOPS increased dramatically between 0 and $0.7 \mu \mathrm{M}$ factor $\mathrm{Va}$ added up to a value approaching $100 \%$ of the added factor Xa (Figure 1). In the absence of factor $\mathrm{Va}$, approximately $10 \%$ of total added factor Xa was associated with these vesicles. Vesicles containing 20\% DOPS instead of $5 \%$ have a relatively high affinity for factor $\mathrm{Xa}$ in the absence of factor $\mathrm{Va}$ and consequently show a less pronounced facilitation of the binding by factor Va.

Figure 2 shows that the amount of prothrombin associated with vesicles that consist of $20 \%$ DOPS increased with increasing factor $\mathrm{Va}$ concentration in the reaction mixture. Contrary to the factor Va facilitated binding of factor $\mathrm{Xa}$, the gradual decrease in prothrombin associated with the vesicles occurred in the presence of factor Va concentrations higher than $0.3 \mu \mathrm{M}$. It is apparent that factor $\mathrm{Va}$ facilitated binding of prothrombin to phospholipid can be observed when the phospholipid-binding sites for prothrombin are not competively removed by factor Va-phospholipid interaction.

The light-scattering technique cannot be used to establish competition between two proteins for the same phospholipidbinding sites, whereas the binding technique used here can. This is seen from Figure 3. The phospholipid-binding properties of factor $\mathrm{Xa}$ were studied in the presence of various amounts of factor $\mathrm{X}$. The double-reciprocal plots of bound vs. free factor $\mathrm{Xa}$ yield straight lines. The respective dissociation constants were $2.1 \times 10^{-7} \mathrm{M}, 4.2 \times 10^{-7} \mathrm{M}$, and 1.0 

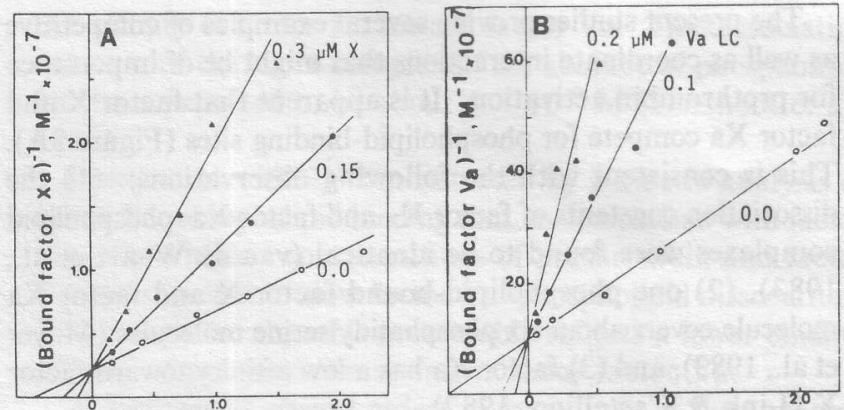

(Free factor $\mathrm{Xa})^{-1}, \mathrm{M}^{-1} \times 10^{-7}$

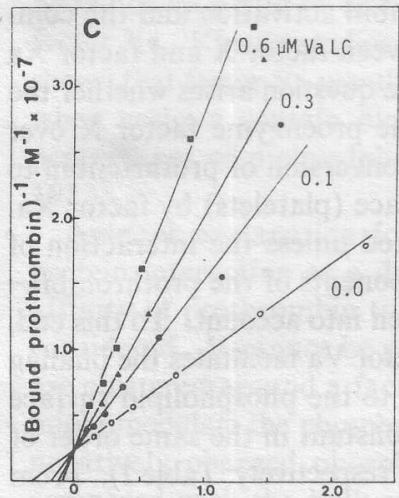

(Free prothrombin) $)^{-1}, M^{-1} \times 10^{-7}$
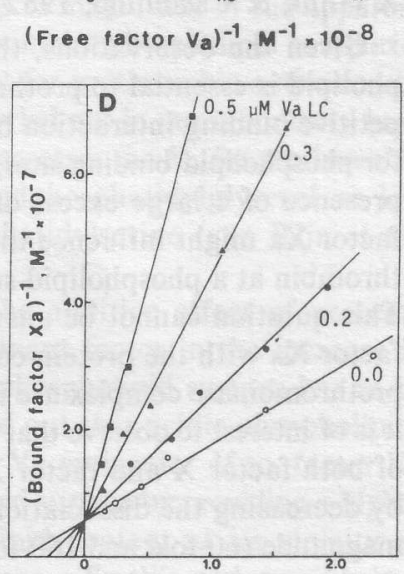

(Free factor $\mathrm{Xa})^{-1}, \mathrm{M}^{-1} \times 10^{-7}$

FIGURE 3: Binding of factor $\mathrm{Xa}$ (A and D), factor $\mathrm{Va}$ (B), and prothrombin (C) to phospholipid (20\% DOPS) in the presence of varying amounts of factor $\mathrm{X}$ and factor Va LC. Phospholipid concentrations were $2.5 \times 10^{-5}(\mathrm{~A}), 1.0 \times 10^{-5}(\mathrm{~B}), 1.0 \times 10^{-4}(\mathrm{C})$, and $1.2 \times 10^{-5} \mathrm{M}(\mathrm{D})$.

$\times 10^{-6} \mathrm{M}$ for no factor $\mathrm{X}$ present and for $1.5 \times 10^{-7} \mathrm{M}$ and $3.0 \times 10^{-7} \mathrm{M}$ factor $\mathrm{X}$ present, respectively (Figure 3A). The maximal binding capacity of the vesicles for factor $\mathrm{Xa}$ was not affected by factor $\mathrm{X}$, indicating that at infinitely large free factor $\mathrm{Xa}$ concentration all factor $\mathrm{X}$ was displaced from the phospholipid surface. These results are consistent with a system of two ligands competing for one class of binding sites with no mutual interactions.

In a completely analogous way, the apparent dissocation constant of factor $\mathrm{Va}$-phospholipid complexes increased with the factor Va LC concentration (Figure 3B). The respective dissociation constants were $2.0 \times 10^{-8} \mathrm{M}, 5.0 \times 10^{-8} \mathrm{M}$, and $1.0 \times 10^{-7} \mathrm{M}$ for no factor Va LC present and for $1.0 \times 10^{-7}$ $\mathrm{M}$ and $2.0 \times 10^{-7} \mathrm{M}$ factor Va LC present, respectively. The competition between factor $\mathrm{Va}$ and factor $\mathrm{Va} \mathrm{LC}$ for the phospholipid binding sites confirms earlier findings that factor $\mathrm{Va}$ and factor Va LC have identical phospholipid-binding properties (van de Waart et al., 1983).

Effect of Factor Va on Equilibrium Binding Data of Prothrombin-, Factor $X-$, and Factor Xa-Phospholipid Interactions. Figure 4A shows that, in the absence of factor $\mathrm{Va}$, the ratio of phospholipid-bound prothrombin to free prothrombin is constant. Apparently, the binding sites are in large excess over the prothrombin molecules. This is consistent with a dissociation constant of $2 \times 10^{-7} \mathrm{M}$ and a maximal prothrombin binding capacity of the vesicles of $2 \times 10^{-7} \mathrm{M}$ prothrombin per $4 \times 10^{-5} \mathrm{M}$ phospholipid (van de Waart et al., 1983). As indicated by the changes in $B / F$ values, the addition of amounts of factor Va, small as compared to the amount of binding sites and comparable to the amount of prothrombin added, yields two distinct classes of prothrombin binding sites.

Analysis of the binding data by double-reciprocal plots of concentration of bound prothrombin vs. concentration of free

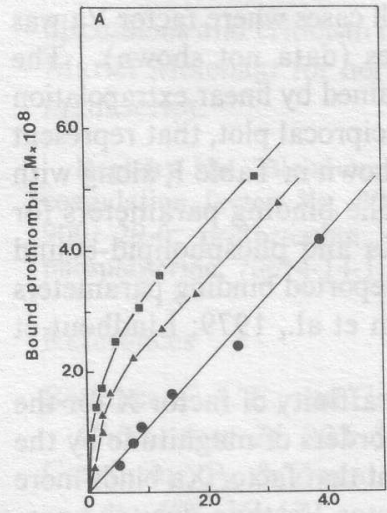

Free prothrombin, $M \times 10^{8}$

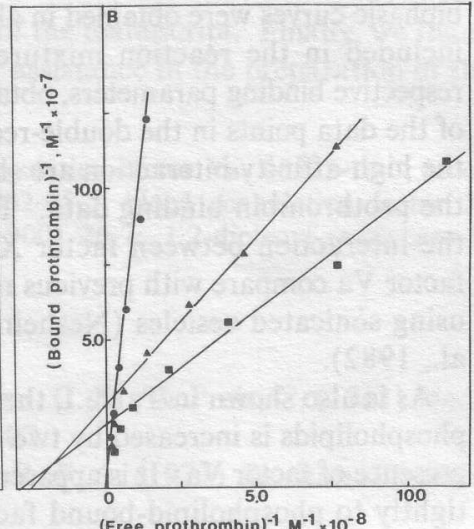

(Free prothrombin) $)^{-1}, M^{-1} * 10^{-8}$
FIGURE 4: Binding of prothrombin to vesicles in the presence of factor Va. (Panel A) The amounts of bound and free prothrombin were determined from reaction mixtures containing no $(\bullet), 3.0 \times 10^{-8}(\mathbf{\Delta})$, or $8.0 \times 10^{-8} \mathrm{M}$ ( ) factor $\mathrm{Va}$, varying amounts of prothrombin ( 0.1 $\times 10^{-7}$ to $1.5 \times 10^{-7} \mathrm{M}$ ), and $4.0 \times 10^{-5} \mathrm{M}$ phospholipid (20\% DOPS). (Panel B) Double reciprocal plots of the binding data from (A).

Table I: Prothrombin-, Factor X-, and Factor Xa-Factor Va Binding Interactions at a Phospholipid Surface

\begin{tabular}{ccccccc}
\hline & \multicolumn{3}{c}{ fixed component } & & \\
\cline { 2 - 4 } $\begin{array}{c}\text { varied } \\
\text { component }\end{array}$ & $\begin{array}{c}\text { pospholipid } \\
\text { DOPS }\end{array}$ & $\begin{array}{c}\text { concn } \\
(\mathrm{M})\end{array}$ & $\begin{array}{c}\text { factor Va } \\
\text { concn }(\mathrm{M})\end{array}$ & $\begin{array}{c}K_{\text {d,app }} \\
(\mathrm{M})\end{array}$ & $n^{a}$ \\
\cline { 2 - 6 } factor Xa & 20 & $2.5 \times 10^{-5}$ & 0 & $1.6 \times 10^{-7}$ & \\
& 10 & $2.5 \times 10^{-5}$ & 0 & $4.0 \times 10^{-7}$ & \\
& 20 & $1.0 \times 10^{-5}$ & $5.0 \times 10^{-9}$ & $1.0 \times 10^{-9}$ & 0.96 \\
& 20 & $1.0 \times 10^{-5}$ & $3.0 \times 10^{-8}$ & $1.2 \times 10^{-9}$ & 0.66 \\
factor X & 10 & $5.0 \times 10^{-5}$ & $6.0 \times 10^{-8}$ & $2.0 \times 10^{-9}$ & 0.73 \\
& 20 & $2.5 \times 10^{-5}$ & 0 & & $1.8 \times 10^{-7}$ & \\
prothrombin & 20 & $2.5 \times 10^{-5}$ & $5.0 \times 10^{-8}$ & $3.0 \times 10^{-9}$ & 1.10 \\
& 20 & $5.0 \times 10^{-5}$ & 0 & & $2.0 \times 10^{-7}$ & \\
& 10 & $5.0 \times 10^{-5}$ & 0 & $4.0 \times 10^{-7}$ & \\
& 20 & $4.0 \times 10^{-5}$ & $3.0 \times 10^{-8}$ & $4.5 \times 10^{-9}$ & 1.2 \\
& 20 & $4.0 \times 10^{-5}$ & $8.0 \times 10^{-8}$ & $4.0 \times 10^{-9}$ & 0.62 \\
& 10 & $4.0 \times 10^{-5}$ & $3.0 \times 10^{-8}$ & $1.5 \times 10^{-8}$ & 0.86 \\
\hline
\end{tabular}

${ }^{a}$ Ratio of moles of protein bound to moles of total added factor $\mathrm{Va}$ at saturation of phospholipid-bound factor $\mathrm{Va}$.

prothrombin showed the presence of high-affinity and lowaffinity phospholipid-binding sites with dissociation constants of $5 \times 10^{-9} \mathrm{M}$ and $1.5 \times 10^{-7} \mathrm{M}$, respectively (Figure 4B).

It is apparent that the high-affinity binding sites comprise factor Va-phospholipid complexes, because the number of high-affinity sites increased with increasing amounts of added factor $\mathrm{Va}$ and nearly $100 \%$ of added factor Va was found to be associated with the vesicles. The apparent stoichiometries between bound prothrombin and bound factor Va were 1.2 and 0.6 at 30 and $80 \mathrm{nM}$ factor Va, respectively. The high number of binding sites with a dissociation constant of $\sim 10^{-7}$ is provided by noncomplexed phospholipid.

Decreasing the DOPS content of the vesicles increased the apparent dissociation constant of prothrombin interaction with phospholipid-bound factor Va, while the number of high-affinity sites appeared not to be dependent on the DOPS content (Table I). This is consistent with the documented increase of the dissociation constants of both proteins with decreasing DOPS content in vesicles and with the observation that, under the experimental conditions used in this study, the amount of phospholipid-bound factor $\mathrm{Va}$ is not significantly dependent on the DOPS content in vesicles.

For reasons of comparison, we investigated the effect of factor $\mathrm{Va}$ on factor $\mathrm{X}$ and factor $\mathrm{Xa}$ binding to vesicles in a similar set of experiments. As in the study with prothrombin, 
biphasic curves were obtained in all cases where factor Va was included in the reaction mixtures (data not shown). The respective binding parameters, obtained by linear extrapolation of the data points in the double-reciprocal plot, that represent the high-affinity interaction are shown in Table I, along with the prothrombin binding data. The binding parameters for the interaction between factor $\mathrm{Xa}$ and phospholipid-bound factor Va compare with previous reported binding parameters using sonicated vesicles (Nesheim et al., 1979; Lindhout et al., 1982).

As is also shown in Table $\mathrm{I}$, the affinity of factor $\mathrm{X}$ for the phospholipids is increased by two orders of magnitude by the presence of factor $\mathrm{Va}$. It is apparent that factor $\mathrm{Xa}$ binds more tightly to phospholipid-bound factor Va than does the proenzyme factor $\mathrm{X}$; the binding constants are $1.1 \times 10^{-9} \mathrm{M}$ and $3.5 \times 10^{-9} \mathrm{M}$, respectively.

Association of Prothrombin and Factor Xa with Phospholipid Vesicles in the Presence of Factor Va LC. The association of prothrombin with vesicles containing $20 \%$ DOPS was determined in the presence of varying amounts of factor $\mathrm{Va}$ LC (Figure 3C). Contrary to the effect observed with factor $\mathrm{Va}$, the dissociation constant of prothrombin-phospholipid complexes increased with increasing factor Va LC concentrations, while the phospholipid to prothrombin ratio at infinite free prothrombin concentration is independent of the amount of factor Va LC present. The relationship between the apparent dissociation constants of prothrombin-phospholipid complexes and factor $\mathrm{Va} \mathrm{LC}$ concentration indicates that prothrombin and factor Va LC compete for phospholipid-binding sites, i.e., acidic phospholipids. Furthermore, it can be concluded that factor Va LC alone does not serve as the binding site for interaction of prothrombin with factor $\mathrm{Va}$.

Also, for the binding of factor $\mathrm{Xa}$ to phospholipid vesicles in the presence of factor $\mathrm{Va} \mathrm{LC}$, a competition between factor $\mathrm{Xa}$ and factor $\mathrm{Va} \mathrm{LC}$ for the phospholipid-binding sites was demonstrated (Figure 3D). It is apparent that the interaction between factor $\mathrm{Va}$ and factor $\mathrm{Xa}$ at the phospholipid surface is not mediated by factor Va LC.

\section{Discussion}

With the use of the simple and direct technique of equilibrium binding on large-volume vesicles, we further studied the role of factor $\mathrm{Va}$ in the assembly and function of the prothrombinase complex. This paper describes as yet unreported equilibrium binding experiments on factor $\mathrm{Va}$-prothrombin complex formation at a phospholipid surface. We also investigated the structure-function relationship between factor $\mathrm{Va}$ as well as its phospholipid-binding subunit (factor $\mathrm{Va}$ LC) and the other components of the prothrombinase complex, i.e., factor $\mathrm{Xa}$ and phospholipid as well as the substrate of the prothrombinase complex prothrombin.

Previous studies of factor $\mathrm{Xa}-$, factor $\mathrm{Va}-$, and prothrombin-phospholipid complexes indicate that the proteins of the prothrombinase complex and the substrate of the complex associate with membranes exclusively through interaction of the proteins with the negatively charged polar head groups of the phospholipids (Pusey et al., 1982; Mayer et al., 1983, and references cited therein; van de Waart et al., 1983). Clustering of acidic phospholipids in membranes of low PS content $(<20 \%)$ probably accompanies these protein-membrane association processes (Mayer \& Nelsestuen, 1981).

Taking these observations together, it is easy to conceive that, depending on the respective protein-protein and protein-phospholipid affinities, coordinate and/or competitive binding interactions might occur between proteins at the phospholipid surface.
The present studies provide several examples of competitive as well as coordinate interactions that might be of importance for prothrombin activation. It is apparent that factor $\mathrm{X}$ and factor Xa compete for phospholipid-binding sites (Figure 3A). This is consistent with the following observations: (1) the dissociation constants of factor $\mathrm{X}$ - and factor $\mathrm{Xa}$-phospholipid complexes were found to be identical (van de Waart et al., 1983), (2) one phospholipid-bound factor X and factor Xa molecule covers about six phosphatidylserine molecules (Mayer et al., 1983), and (3) factor Xa has a low affinity toward factor X (Link \& Castellino, 1982).

Given the observations, that factor $\mathrm{Xa}$ binding to phospholipid is essential to prothrombin activation and the competitive binding interaction between factor $\mathrm{X}$ and factor $\mathrm{Xa}$ for phospholipid-binding sites, the question arises whether the presence of a large excess of the proenzyme factor $\mathbf{X}$ over factor Xa might influence the conversion of prothrombin to thrombin at a phospholipid surface (platelets) by factor Xa. This question cannot be answered unless the interaction of factor Xa with the protein components of the prothrombinprothrombinase complex are taken into account. To this end, it is of interest to observe that factor $\mathrm{Va}$ facilitates the binding of both factor $\mathrm{X}$ and factor $\mathrm{Xa}$ to the phospholipid surface by decreasing the dissociation constant in the same order of magnitude (60-fold and 160-fold, respectively; Table I). From these results, the notion arises that factor $\mathrm{X}$ might be able to remove factor $\mathrm{Xa}$ from factor $\mathrm{Xa}$-factor $\mathrm{Va}$ complexes competitively and thus reduce the amount of functional phospholipid-bound enzyme. Preliminary data from kinetic studies on prothrombin activation have given support to this possibility (unpublished results).

Apart from its function in the assembly of the prothrombinase complex, factor $\mathrm{Va}$ increases the catalytic efficiency of the enzyme (Rosing et al., 1980). This suggests a role for factor $\mathrm{Va}$ in the interaction between prothrombinase and substrate (prothrombin). The equilibrium binding studies presented here indicate that factor $\mathrm{Va}$ facilitates the binding of prothrombin to the phospholipid surface. Under the conditions of the experiments, of which the results are presented in Table I, factor Va decreases the dissociation constant of prothrombin-phospholipid (20\% DOPS) complexes approximately 40 -fold. We have to emphasize that we are dealing with apparent dissociation constants, dependent on the DOPS content of the vesicles. It appears from Figure 2 that, at high factor $\mathrm{Va}$ concentrations, the amount of prothrombin bound to the vesicle decreases with increasing factor $\mathrm{Va}$ concentration. This strongly suggests that the additive effect of proteinprotein interaction as an important factor in facilitating the binding of one of the components, i.e., prothrombin, to the phospholipid surface is abolished by a competition with factor $\mathrm{Va}$ for the same binding sites. In accordance with this notion, there appears to be a 3-fold increase in the apparent dissociation constant of prothrombin-phospholipid complexes in the presence of factor $\mathrm{Va}$ when the DOPS content of the vesicles is lowered from $20 \%$ to $10 \%$ (Table I). A comparison of these results with the data obtained under identical conditions from factor $\mathrm{Xa}$ binding studies in the presence of factor $\mathrm{Va}$ reveals that (1) the apparent dissociation constant of factor $\mathrm{Xa}$-phospholipid complexes in the presence of factor $\mathrm{Va}$ is approximately 5-fold lower, (2) decreasing the DOPS content of the vesicles has less effect on the dissociation constant, and (3) factor $\mathrm{Xa}$ is not competitively removed from the phospholipid by high factor Va concentrations (Figure 1). These findings can be qualitatively rationalized by assuming that the affinity of prothrombin toward factor $\mathrm{Va}$ is much less than 
the affinity of factor Xa toward factor Va. The dissociation constant of the latter complex in the absence of phospholipid has been reported to be about $4 \times 10^{-9} \mathrm{M}$ (Lindhout et al., 1982).

Pusey et al. (1982) demonstrated by a kinetic analysis of factor Va-phospholipid binding that, in comparison with factor $\mathrm{Xa}$, much higher concentrations of prothrombin and factor $\mathrm{X}$ were required to slow factor $\mathrm{Va}$-phospholipid dissociation. They suggested that this presumably reflects a lower binding affinity of prothrombin or factor X for factor Va.

A decrease of several orders of magnitude of the apparent dissociation constant of prothrombin-phospholipid complexes by factor Va might be relevant for prothrombin activation by factor Xa. Kinetic studies carried out in our laboratory have shown that factor Va greatly decreases the $K_{\mathrm{m}}$ for prothrombin when vesicles contain dioleoylphosphatidylglycerol or low percentages of dioleoylphosphatidylserine (van Rijn et al., 1983).

Another explanation for the additive effect of proteinprotein interaction as a dominant factor in the increase in affinity of prothrombin to a phospholipid surface has to be considered. It cannot be ruled out that acidic phospholipids are clustered around a factor $\mathrm{Va}$ molecule. If so, factor $\mathrm{Va}$ might modulate the phospholipid surface by providing a higher negatively charged phospholipid content at its vicinity as compared with the bulk surface. To this end, equilibrium binding studies were performed that utilized the phospholipid-binding subunit of factor $\mathrm{Va}$ (factor $\mathrm{Va} \mathrm{LC}$ ).

We demonstrated that the dissociation constants of factor $\mathrm{Xa}-$, prothrombin-, and factor $\mathrm{Va}$-phospholipid complexes increase with the concentration of factor Va LC. Because the phospholipid-binding properties of factor Va LC are identical with those of factor $\mathrm{Va}$, we conclude from these observations that modulation of the phospholipid surface by factor $\mathrm{Va}$ is not enhancing the interaction of phospholipid with prothrombinase proteins.

In addition, the results of this study also provide us with information about the structure-function relationship between factor Va subunits and the other protein components of the prothrombinase complex, factor $\mathrm{Xa}$, as well as prothrombin. In contrast to the findings of Tracy \& Mann (1983) utilizing platelets, we could not establish that the 80000 -dalton component of factor $\mathrm{Va}$ (factor $\mathrm{Va} \mathrm{LC}$ ) also serves as the binding site for interaction of factor Xa with phospholipid-bound factor $\mathrm{Va}$. Our results confirm previously reported evidence that the $\mathrm{Ca}^{2+}$-mediated interaction between the two subunits of factor $\mathrm{Va}$ is required for binding of factor $\mathrm{Va}$ to factor $\mathrm{Xa}$ (Lindhout et al., 1982).

\section{Acknowledgments}

We thank Harry Bruls for his technical assistance. We also thank Drs. Margaret Rand and Jan Rosing for their valuable discussions and criticism of the manuscript. Finally, we thank Mariet Molenaar for her assistance in the preparation of the manuscript.

Registry No. Blood coagulation factor Va, 65522-14-7; blood coagulation factor $\mathrm{Xa}, 9002-05-5$; blood coagulation factor $\mathrm{X}$, 9001-29-0; prothrombin, 9001-26-7; 1,2-dioleoyl-sn-glycero-3phosphoserine, 70614-14-1.

\section{References}

Böttcher, C. I. E., van Gent, C. M., \& Preis, C. (1961) Anal. Chim. Acta 24, 203-307.

Comfurius, P., \& Zwaal, R. F. A. (1977) Biochim. Biophys. Acta 488, 36-42.

Deamer, D., \& Bangham, A. D. (1976) Biochim. Biophys. Acta 443, 629-634.

Esmon, C. T., \& Jackson, C. M. (1974) J. Biol. Chem. 249 , 7791-7797.

Fujikawa, K., Legaz, M. E., \& Davie, E. W. (1972a) Biochemistry 11, 4882-4891.

Fujikawa, K., Legaz, M. E., \& Davie, E. W. (1972b) Biochemistry 11, 4891-4899.

Lindhout, T., Govers-Riemslag, J. W. P., van de Waart, P., Hemker, H. C., \& Rosing, J. (1982) Biochemistry 21, 5494-5502.

Link, R. P., \& Castellino, F. J. (1982) Arch. Biochem. Biophys. 215, 215-221.

Mayer, L. D., \& Nelsestuen, G. L. (1981) Biochemistry 20, 2457-2463.

Mayer, L. D., Nelsestuen, G. L., \& Brockman, H. C. (1983) Biochemistry 22, 316-321.

Nelsestuen, G. L., \& Lim, T. K. (1977) Biochemistry 16, 4164-4171.

Nesheim, M. E., Taswell, J. B., \& Mann, K. G. (1979) J. Biol. Chem. 254, 10952-10962.

Owen, W. G., Esmon, C. T., \& Jackson, C. M. (1974) J. Biol. Chem. 249, 594-605.

Pusey, M. L., Mayer, L. D., Wei, G. J., Bloomfield, V. A., \& Nelsestuen, G. L. (1982) Biochemistry 21, 5262-5269.

Rosing, J., Tans, G., Govers-Riemslag, J. W. P., Zwaal, R. F. A., \& Hemker, H. C. (1980) J. Biol. Chem. 255, 274-283.

Tracy, P. B., \& Mann, K. G. (1983) Proc. Natl. Acad. Sci. U.S.A. 80, 2380-2384.

Tracy, P. B., Nesheim, M. E., \& Mann, K. G. (1981) J. Biol. Chem. 256, 743-751.

van de Waart, P., Bruls, H., Hemker, H. C., \& Lindhout, T. (1983) Biochemistry 22, 2427-2432.

van Dieijen, G., Tans, G., Rosing, J., \& Hemker, H. C. (1981) J. Biol. Chem. 256, 3433-3442.

van Rijn, J. L. M. L., Govers-Riemslag, J. W. P., Zwaal, R. F. A., \& Rosing, J. (1983) Thromb. Haemostasis 50, 406. 